\title{
矩形曲がり管内二次流の形態変化*
}

\author{
山 本 恭 二*1, 門 脇 健*2 \\ 柳 瀬 真一郎*1, 加 賀 義 人*1 $^{* 1}$
}

\section{Pattern Variation of the Secondary Flow in Rectangular Curved Ducts}

\author{
Kyoji YAMAMOTO*3, Ken KADOWAKI, \\ Shinichiro YANASE and Yoshito KAGA \\ ${ }^{* 3}$ Department of Mechanical Engineering, Okayama University,
}

3-1-1 Tsushima-naka, Okayama-shi, Okayama, 700-8530 Japan

\begin{abstract}
The flow through a rectangular curved duct is investigated numerically with emphasis on the secondary flow patterns. The non-dimensional curvature of the duct is taken to be 0.02 and the aspect ratios of the duct cross-section are considered to be $0.5,2,3$ and 4 . The calculation covers a wide range of the Dean number. The steady solutions are first calculated and then the linear stability of the solutions is examined. The multiple solutions and the bifurcation of the solutions are obtained. The critical Dean numbers at which the transition of the secondary flow patterns occurs are also obtained.
\end{abstract}

Key Words: Curved Duct Flow, Secondary Flow, Dean Number, Rectangular Cross-Section, Linear Stability

\section{1. 序}

曲がり管は，流体輸送の管路系の一部としては勿 論, 放熱器あるいは混合器として工業上広く用いられ ているが，この他にも，血管のような生物内の流体輸 送系においても見られる管路である. 曲がり管内の流 れは，曲がりによる遠心力によって，管断面内におい て，遠力方向に対称面を持ち，互いに反対方向に回 転する二つの渦（ディーン渦）が発生し，これによっ て，管の流動抵抗や流体混合が影響されることから， 古くから多くの研究がなされてきた(1). 近年では, 詳 細な数值解析に基ついて, 管の形狱や流れの圧力勾配 などが同じ状態であるにもかかわらず，管内部の流動 状態が異なるいくつかの解が存在（多重解の存在）す ることや，流れのパラメータの変化に伴って解の分岐 が現れることなどが明らかにされ(2)(3)，数学的な観点 からの曲がり管内流に対する関心を引いている.

本研究に関連した矩形断面形状を持つ曲がり管内 流の従来の研究について言えば, Cheng ら(4)は, いく つかの断面継横比とディーン数に対して，矩形曲がり 管内流の数值解析を行っている. そして, 通常のディ 一ン渦の他に，附加的な渦を持つ4つ洞流れを見出し

* 原稿受付 2004 年 2 月 18 日

*1 正員, 岡山大学工学部 ( 700-8530 岡山市津島中 3-1-1)

*2 正員, 松江工業高等専門学校機械工学科(690-8518 松江 市西生馬町 14-4).

E-mail : yamamoto@fluid.mech.okayama-u.ac.jp
ている. 秋山ららは，小さい縦横比から大きい維横比 に渡る矩形断面形状の管に対して，数值計算と実験に より，断面内の二次流渦についての研究を行い，附加 的な渦の発生するディーン数について調べている. さ らに，杉山ら(6)は，継横比が 0.5 から 2.5 における矩 形曲がり管内二次流の可視化実験を行い，ディーン数 の変化に伴う渦模様の変化を調べると同時に, 附加渦 の発生するディーン数についても言及している. Winters(2)は，正方形断面を持つ曲がり管内流の数值 解析に基づく詳細な研究を行っている. その結果, 解 の分岐と通常のディーン渦以外の二次流渦形状を見出 し, 流れの安定性を調べることにより, 二つの渦から なる二次流以外は不安定であると述べている. 一方, 柳瀬ら (3)(7)(8)は，ディーン数が 100 という比較的小さい 場合ではあるが，広い簛囲の断面繸横比に対し数值解 析を行っている. その結果, 多重解の存在, 解の分岐 が明らかにされると同時に，流れの線型安定性を調べ ることにより，どの流れが実際に生ずるかを明らかに した. この研究は, しかしながら, ディーン数が 100 の場合に限られており，矩形管内流に対して，大きな ディーン数に対する多重解や解の分岐については，未 だ理論的に調べられていない，そこで本研究において は, この点を調べることによって, 附加渦の発生限界 を明らかにすること, また, ディーン数の変化と共に 二次流模様がどのように変化していくかを明らかにし 
たい，すなわち，矩形断面を持つ曲がり管内の十分発 達した層流に対し，広いディーン数に渡る定常解を数 值的に求め, 更に, 得られた解に対し, 線型安定性を 調べることにより，管断面に生ずる二次流の形態変化 を明確に把握しようとしている.

\section{2. 基磷方程式}

幅が $2 d ，$ 高さが $2 h$ である矩形断面をした曲がり 管を考える. 図 1 に使用する座標系を示す.ここで, $\left(r^{\prime}, \theta, z^{\prime}\right)$ は， $\theta$ を円周角とする円柱座標であり， $s^{\prime}$ は管の中心線に沿う座標である. 中心線 $s^{\prime}$ のな寸曲 率半径は一定であり， $R_{0}$ とする. 流体の密度を $\rho$, 粘性係数を $\mu$ として, 次の無次元量を導入する.

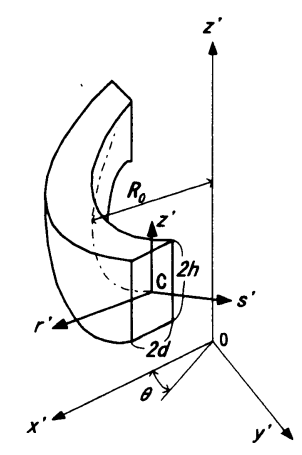

Fig. 1 Coordinates system

$$
\begin{aligned}
& t^{\prime}=\frac{\rho d^{2}}{\mu} t, \quad r^{\prime}=d r=d\left(\delta^{-1}+\eta\right), \quad z^{\prime}=d z, \\
& s^{\prime}=R_{0} \theta=d s \\
& u^{\prime}=\frac{\mu}{\rho d} u, \quad v^{\prime}=\frac{\mu}{\rho d} \frac{v}{\sqrt{2 \delta}}, \quad w^{\prime}=\frac{\mu}{\rho d} w, \\
& p^{\prime}=\frac{\mu^{2}}{\rho d^{2}} p
\end{aligned}
$$

ここで, $t^{\prime}$ は時間， $u^{\prime}, v^{\prime}, w^{\prime}$ は，それぞれ，半径 $\left(r^{\prime}\right)$, 軸 $\left(s^{\prime}\right)$ およひ垂直方向 $\left(z^{\prime}\right)$ の流速, $p^{\prime}$ は圧力であり, ダッシュ(')のないものは無次元量である. また,

$$
\delta=d / R_{0}
$$

は無次元曲率であり，管断面の綐横比 $\gamma$ を

$$
\gamma=h / d
$$

とおく. さらに, $z$ 方向座標に対し,

$$
\zeta=z / \gamma
$$

を導入する，一定の圧力勾配 $G$ によって生ずる流れ は，管軸 $s$ に沿って変化しないものとする. このとき 連続の式

$$
\frac{\partial u}{\partial \eta}+\frac{\partial w}{\gamma \partial \zeta}+\frac{u \delta}{1+\eta \delta}=0
$$

を考虑して, 流れ関数 $\psi$ を導入する. すなわち,

$$
u=\frac{1}{1+\delta \eta} \frac{\partial \psi}{\gamma \partial \zeta}, \quad w=-\frac{1}{1+\delta \eta} \frac{\partial \psi}{\partial \eta}
$$

また $s=0$ での断面内の圧力を $p_{1}(t, \eta, \zeta)$ で表せば, 圧力 $p$ は,

$$
p=-\frac{D_{n}}{\sqrt{2 \delta}} s+p_{1}
$$

となる. ここで, $D_{n}$ はディーン数であり, 次のよう に定義される.

$$
D_{n}=\frac{\rho \sqrt{2 \delta} d^{3} G}{\mu^{2}}
$$

さて, $\eta$ および $\zeta$ 方向の運動方程式より圧力 $p_{1}$ を消 去した式, 並びに, $s$ 方向の式において, 流れ関数 $\psi$ を用いると基碮式は次のようになる。

$$
\begin{aligned}
& (1+\delta \eta) \frac{\partial v}{\partial t}+\frac{1}{\gamma} \frac{\partial(v, \psi)}{\partial(\eta, \zeta)}=D_{n}-\frac{\delta^{2} v}{1+\delta \eta} \\
& +(1+\delta \eta) \Delta v-\frac{1}{\gamma} \frac{\delta}{1+\delta \eta} \frac{\partial \psi}{\partial \zeta} v+\delta \frac{\partial v}{\partial \eta} \cdots \cdots(9) \\
& \left(\Delta-\frac{\delta}{1+\delta \eta} \frac{\partial}{\partial \eta}\right) \frac{\partial \psi}{\partial t}+\frac{1}{\gamma} \frac{1}{1+\delta \eta} \frac{\partial(\Delta \psi, \psi)}{\partial(\eta, \zeta)} \\
& =\frac{1}{\gamma} v \frac{\partial v}{\partial \zeta}+\Delta^{2} \psi+\frac{1}{\gamma} \frac{\delta}{(1+\delta \eta)^{2}} \times \\
& \left\{\frac{\partial \psi}{\partial \zeta}\left(2 \Delta \psi-\frac{3 \delta}{1+\delta \eta} \frac{\partial \psi}{\partial \eta}+\frac{\partial^{2} \psi}{\partial \eta^{2}}\right)-\frac{\partial \psi}{\partial \eta} \frac{\partial^{2} \psi}{\partial \eta \partial \zeta}\right\} \\
& +\frac{\delta}{(1+\delta \eta)^{2}}\left\{-2(1+\delta \eta) \frac{\partial \Delta \psi}{\partial \eta}+\delta \Delta \psi\right. \\
& \left.+2 \delta \frac{\partial^{2} \psi}{\partial \eta^{2}}-\frac{3 \delta^{2}}{1+\delta \eta} \frac{\partial \psi}{\partial \eta}-\frac{\delta}{\gamma^{2}} \frac{\partial^{2} \psi}{\partial \zeta^{2}}\right\} \cdots \cdots(10)
\end{aligned}
$$

ただし， 


$$
\begin{aligned}
& \Delta=\frac{\partial^{2}}{\partial \eta^{2}}+\frac{1}{\gamma^{2}} \frac{\partial^{2}}{\partial \zeta^{2}}, \\
& \frac{\partial(f, g)}{\partial(\eta, \zeta)}=\frac{\partial f}{\partial \eta} \frac{\partial g}{\partial \zeta}-\frac{\partial f}{\partial \zeta} \frac{\partial g}{\partial \eta}
\end{aligned}
$$

また，壁面での境界条件は，

$$
\begin{aligned}
& v( \pm 1, \zeta)=v(\eta, \pm 1)=0 \\
& \psi( \pm 1, \zeta)=\psi(\eta, \pm 1)=0 \\
& \frac{\partial \psi}{\partial \eta}( \pm 1, \zeta)=\frac{\partial \psi}{\partial \zeta}(\eta, \pm 1)=0
\end{aligned}
$$

得られた解を用いて, 管内の流量 $Q^{\prime}$ は次式により求 められる.

$$
\begin{aligned}
& Q^{\prime}=\int_{-h}^{h} d z^{\prime} \int_{-d}^{d} v^{\prime} d r^{\prime}=\frac{\mu d}{\rho \sqrt{2 \delta}} Q, \\
& Q=\gamma \int_{-1}^{1} d \zeta \int_{-1}^{1} v d \eta
\end{aligned}
$$

また, 平均流速 $\overline{v^{\prime}}$ は,

$$
\overline{v^{\prime}}=\frac{Q^{\prime}}{4 h d}=\frac{\mu}{4 d \gamma \rho \sqrt{2 \delta}} Q
$$

となる. ここで, 水力直径 $d_{h}$ を導入する.

$$
d_{h}=\frac{4 h d}{h+d}=\frac{4 \gamma}{\gamma+1} d
$$

レイノルズ数は,

$$
R_{e}=\frac{\overline{v^{\prime}} d_{h} \rho}{\mu}=\frac{Q}{\sqrt{2 \delta}(\gamma+1)}
$$

で与えられる. また，管摩擦係数入は，次式で定義 される.

$$
G=\frac{\lambda}{d_{h}} \frac{\rho}{2}\left(v^{\prime}\right)^{2}
$$

これによりえは，次のように表せる.

$$
\lambda=\frac{128 \gamma^{3} \sqrt{2 \delta}}{(1+\gamma) Q^{2}} D_{n}
$$

\section{3. 数 值計 算 法}

基硅式(9)，(10)は，後述するように，流れの安定性 解析のために非定常項を含んでいるが，まず最初に， 一定圧力勾配のもとで，どんな定常解が得られるが ついて調べる. 従って, 式(9),(10)において時間微分を 含まない式の解を求める. 数値計算には，以前から用 いられているチェビシェフ多項式に基づくスペクトル 法(7)(8)(9)を用いる. すなわち，境界条件(12)，(13)を考虑
して， $\psi$ およびvをチェビシェフ多項式を用いて次 のように表す。

$$
\begin{aligned}
& \psi(\eta, \zeta)=\left(1-\eta^{2}\right)^{2}\left(1-\zeta^{2}\right)^{2} \sum_{m=0}^{M} \sum_{n=0}^{N} \psi_{m n} T_{m}(\eta) T_{n}(\zeta) \cdots(19) \\
& v(\eta, \zeta)=\left(1-\eta^{2}\right)\left(1-\zeta^{2}\right) \sum_{m=0}^{M} \sum_{n=0}^{N} v_{m n} T_{m}(\eta) T_{n}(\zeta) \cdots(20) \\
& こ こ て ゙, \\
& T_{n}(x)=\cos (n \cdot \arccos (x)) \quad \cdots \ldots \ldots \ldots \ldots \ldots(21)
\end{aligned}
$$

は, $n$ 次のチェビシェフ多項式であり, $\psi_{m n}, v_{m n}$ は 求めるべき未定定数， $M, N$ は，それぞれ， $\eta, \zeta$ 方 向の級数打ち切り項数である. 級数展開(19), (20)を式 （9）（10）（但し，時間微分項は省略）に代入し，選点 法(9)を用いることにより，未定定数 $\psi_{m n}, v_{m n}$ に対する 代数方程式を得る. この方程式をニュートン法を用い て解く.なお，選点としては，

$$
\begin{array}{r}
\eta_{i}=\cos \left(\frac{\pi \cdot i}{M+2}\right), \quad \zeta_{j}=\cos \left(\frac{\pi \cdot j}{N+2}\right) \cdots \cdots \\
(i=1, \cdots, M+1, \quad j=1, \cdots, N+1)
\end{array}
$$

を取っている. また，解の収束判定として，

$$
\varepsilon=\sum_{m=0}^{M} \sum_{n=0}^{N}\left[\left(\psi_{m n}{ }^{(\ell+1)}-\psi_{m n}{ }^{(\ell)}\right)^{2}+\left(v_{m n}{ }^{(\ell+1)}-v_{m n}{ }^{(\ell)}\right)^{2}\right]
$$

において， $\varepsilon<10^{-10}$ を用いている.ここで, $\ell$ は， 解の繰り返し回数である. また, 級数打切り項数 $M, N$ は，断面綐横比 $\gamma$ によって異なっているが, 最小で $M=30, N=20$ ，最大で $M=30, N=80$ を 取った.

次に，このようにして得られた定常解に対し，微 小擋乱を加えたときの解の挙動について調べる. 解析 の方法については，文献(3)に示されているので, ここ ではその方法を略述するに止める.すなわち， $\widetilde{\psi}(\eta, \zeta), \widetilde{v}(\eta, \zeta)$ を得られた定常解として,

$$
\begin{aligned}
& \psi(\eta, \zeta, t)=\widetilde{\psi}(\eta, \zeta)+\hat{\psi}(\eta, \zeta) e^{\sigma t} \\
& v(\eta, \zeta, t)=\widetilde{v}(\eta, \zeta)+\hat{v}(\eta, \zeta) e^{\sigma}
\end{aligned}
$$

とおく.ここで, $\hat{\psi}, \hat{v} は$ 微小変動を表す.

$\sigma=\sigma_{R}+\sigma_{I} i(i=\sqrt{-1}) \quad$ は，時間的変化を表す項で あり, $\sigma_{R}<0$ なら微小変動は時間と共に减少, $\sigma_{R}>0$ なら変動は増大し, 定常解は不安定となり, そのままでは存在しえないことを示唆している. 式 
(24)を，時間項を含む(9)，(10)に代入し， $\widetilde{v}, \widetilde{\psi} か ゙$ 定常解 であることと, 微小量 $\hat{v}, \hat{\psi}$ の二次以上を省略するこ

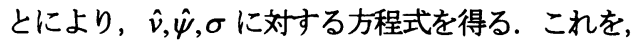
定常解を求める際と同じく, $\hat{v}, \hat{\psi}$ のチェビシェフ展 開と選点法の利用により， $\sigma$ に対する固有值方程式 を得る. これを解くことにより, 固有値 $\sigma$ を求める ものである. チェビシェフ展開における級数打ち切り 項数 $M, N$ は, 定常解と同じ值を用いた. 固有值 $\sigma$ は, $\sigma_{R}$ の值の大きい順に求められるが, $M, N$ を変 えても, 最大 $\sigma_{R}$ の值は, ほとんど変化せず, 安定・ 不安定を判別する固有值正しく求められていると考 えられる. なお, 本研究では, 式(24)に示したように, 微小変動は，断面内の変化だけの二次元的な変動に限 定しており, そのような変動に対し, 得られた定常解 が, 安定に存在するかどうかを判別しようとしている.

\section{4. 定常な二次流形慗と安定性}

管断面の粉横比 $\gamma$ が 0.5, 2, 3, 40場合を考える. ま た, 比較的小さな曲率を持つ曲がり管を取り, 無次元 曲率 $\delta$ を 0.02 とする. Wintersひによれば, $\gamma=1$ の

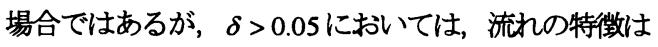
$\delta$ の值によって大きく異なるが, $\delta<0.05$ では, 曲 率の影禦は比較的小さいということである. 従って, 本研究では，曲率の小さい曲がり管に対する流れの特 徵を明らかにするために, $\delta=0.02$ を取り計算を行 う.

(i) $\gamma=0.5$ の場合

図 2 に, ディーン数 $D_{n}$ を変えたときの流量 $Q$ の変 化を示す. この図の右側の軸はレイノルズ数 $R_{e}$ を表 す. この図中に示された四角内の部分を搪大した図を 図 3に示す。図の実線は, 得られた流れが安定な場合 を，また，鎖線および点線は不安定な場合を示してい る. この内, 鎖線は得られた固有值の実部 $\sigma_{R}$ が $0<\sigma_{R}<10$ の場合を, また, 点線は $\sigma_{R}>10$ の場合を 表している. これは, たとえ流れが不安定であっても, その度合が小さい場合には，曲がり管入口から流れの 観測点までが長くない曲がり流路の実験においては, 二次流が観察されることがあるかも知れないという予 測から便宜上二つに分けているものである.

すなわち，変動の拡大率 $e^{\sigma_{\mathrm{R}} t} に お い て ，$

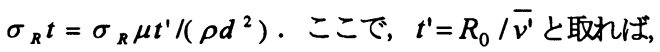
$\sigma_{R} t=4 \gamma \sigma_{R} /(\gamma+1)^{-1}\left(R_{e} \delta\right)^{-1}$ となる. 従って, $\sigma_{R}=10 ， \delta=0.02$ のとき, 例えば $R_{e}=1000$, $\gamma=3$ に対し, $\sigma_{R} t=1.5$ となり, 変動は十分小さい.

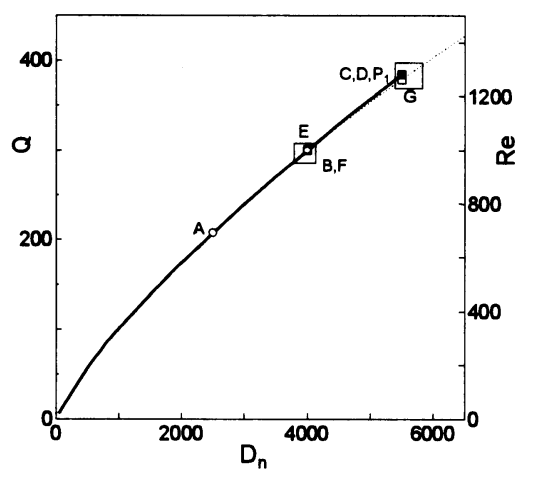

Fig.2 $Q$ versus $D_{n} \quad(\gamma=0.5)$

図に示されているように, $3773<D_{n}<5523$ の範 囲において，三重解が得られたが，流量の違いは僅か であることが見られる. 誘起される流れが, ディーン 数とともにどのように変化するか, 三重解がどのよう な流れ模様を示切を明らがするため, 図 2 中の A 〜 Gの点での, 断面内の二次流流線模様を, 図 4 に示 す.ここで, 図中の数字は $\psi$ の值を表し， $\psi<0$ の 流線を鎖線で表す. $\psi<0$ は時計回り， $\psi>0$ は反時 計回りの渦を表している.

図 2，3 中の○は二次流が二つ渦の場合，口は四つ 渦を表す. また, ははこの点で, 渦の形が変化する位 置を表している. この図より分かるように，流量を表 す線図に沿って $D_{n}$ が，小さい值から増吋する場合， 通常のディーン渦 (二つ渦) が現れる.この二つ渦は $D_{n} \cong 5500$ の点 $\mathrm{P}_{1}$ 迄続き，その後は四つ渦を持つ. この二次流は, 流量が折り返しとなる $D_{n} \cong 5520$ ま では安定であるが，折り返し点後しばらくはやや不安 定 $\left(0<\sigma_{R}<10\right)$ となる. 流量線図に沿って $D_{n}$ が減少 する時, 点 $\mathrm{D}, \mathrm{E}$ を経て $D_{n} \cong 3773$ 附近で折り返し, $\mathrm{F}, \mathrm{G}$ 一と変化していく.

この間，図 4に見られるように，断面右中央にある 副渦は成長していく. なお, 線型安定解析における微 小変動のうち最大の $\sigma_{R}$ を持つ変動は, ディーン数が 1000 附近を除いた大部分の領域で, 時間と共に単調

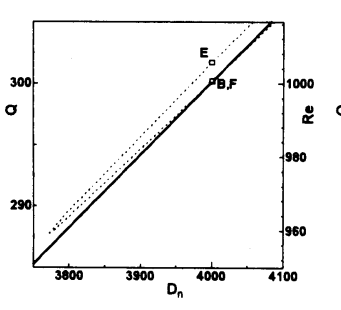

(a)

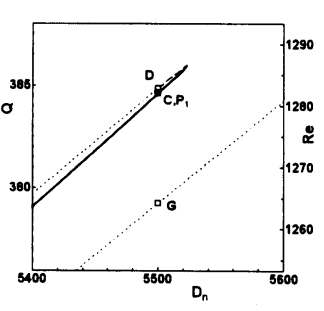

(b)
Fig.3 $Q$ versus $D_{n} \quad(\gamma=0.5)$ 
減少あるいは単調增大を行うことが認められた，図 2 中の $\mathrm{A} \sim \mathrm{G}$ 点における最大 $\sigma_{R}$ に対する固有値 $\left(\sigma_{R}, \sigma_{I}\right)$ を示すと, $\mathrm{A}:(-30.09,0)[(-30.09,0)]$, B : $(-34.30,0)[(-34.30,0)], C:(-12.00,0)[(-$ $12.09,0)], \mathrm{D}:(11.20,0)[(11.19,0)], \mathrm{E}:(53.45,0)$ $[(53.45,0)], \mathrm{F}:(50.85,0)[(50.84,0)], \mathrm{G}:(46.03$, 0) $[(46.50,0)]$ である. ここで（）内の值は，打ち 切り項数 $(M, N)$ が $(30,20)$ の場合， [ ] 内の值は $(40,30)$ の場合であり，打ち切り項数による違いは小さい，ま た, 副渦が出現する直前の点 $\mathrm{C}$ と, 変動が不安定で ある点 $\mathrm{G}$ における最大 $\sigma_{R}$ を持つ変動模様（固有関 数）を示すと図 5 のようになる.この図に見られるよ うに，変動が副渦 (発生) 附近に集中していることは 興味深い:

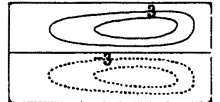

(A)

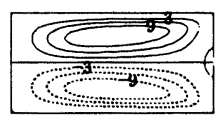

(D)

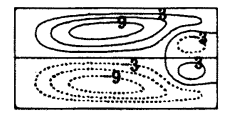

(G)

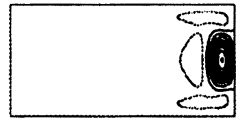

(a) $v$

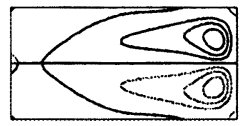

(b) $\psi$

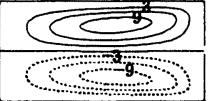

(B)

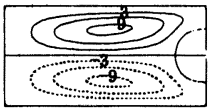

(E)

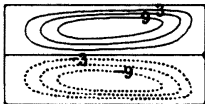

(C)

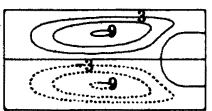

(F)
Fig.4 Secondary flow patterns $(\gamma=0.5): \quad D_{n}=2500(\mathrm{~A}), 4000(\mathrm{~B})$, $5500(\mathrm{C}), 5500(\mathrm{D}), 4000(\mathrm{E}), 4000(\mathrm{~F})$, $5500(G)$.
(A) point $\mathrm{C}$

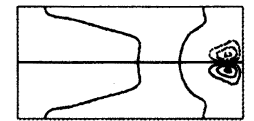

(a) $v$

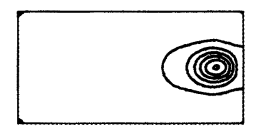

(b) $\psi$

(B) point $G$
Fig.5 Eigen functions with the largest $\sigma_{R}$

本研究では, 四つ渦は, $D_{n} \cong 5500$ 従って $R_{e} \cong 1282$ 程度のときに現れる. 杉山ら(6)の実験（図 $2(\mathrm{~b}), \delta=0.0625)$ によると, $D_{e}=261$ において四つ渦 が現れているが, $D_{e}=R_{e} \sqrt{2 \delta}$ の関係があることか ら, $R_{e}=1282$ に対しては $D_{e}=256$ となり $\delta$ の相
違にか功わらず杉山らの実験によく一致した値となる.

(ii) $\gamma=2$ の場合

図 6および7に, ディーン数 $D_{n}$ を変えたときの流

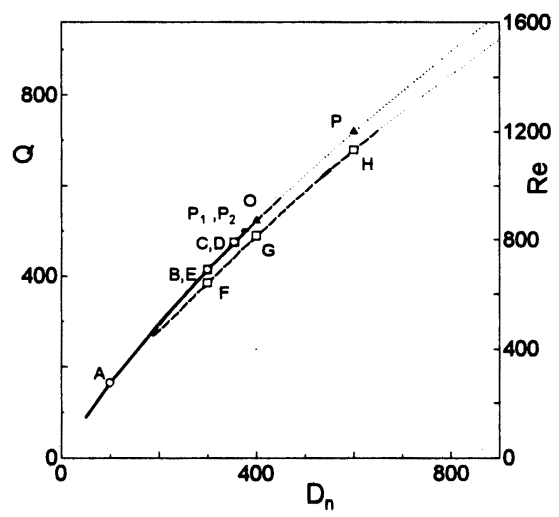

Fig.6 $Q$ versus $D_{n} \quad(\gamma=2)$

量 $Q$ の変化を示す，図中の記号等は，図 2,3 と同じ 意味を持つが，新たな記号として， $\Delta$ は非対称な二次 流，日は四つ渦だが中央部の渦が大きく広がっている

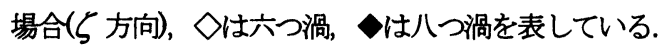
図 6,7 中の点 $\mathrm{A} \sim \mathrm{P}$ および $\mathrm{a}$ e での二次流模様を図 8 および 9 に示寸，二次流の変化を流量線図に基つい て説明すると次のようになる. 図 6 において $D_{n}$ の小 さいところ，例えば $\mathrm{A}$ 点では，図 8(A) に示されたよ うな二つ渦である．流量線図に沿って $D_{n}$ が増加する とき, 点 $\mathrm{B}, \mathrm{C}$ を通り， $D_{n} \cong 381$ 近くで折り返す. ここまで, 流れは安定である. その後, $D_{n}$ の減少と 共に $\mathrm{P}_{1}, \mathrm{D}, \mathrm{E}$ を経て， $D_{n} \cong 186$ 附近で再ひ折り返す。 そして， $D_{n}$ の增加につれて， $Q$ は增大し，点 $\mathrm{F}, \mathrm{G}, \mathrm{H}$ を通る。最初の折り返し点近くの $\mathrm{P}_{1}\left(D_{n} \cong 376\right)$ において, 二次流は二つ渦加四つ渦 一と変化し，流量線図に沿って小さな形の副渦が発展 する. この様子は，図 8(D) （H)において明らかで あろう. なお，最初の折り返し点以後， $D_{n} \cong 650$ ま では，流れは弱い不安定であるが， $530<D_{n}<550$ では，安定であることが分かった. 折り返し点近くの $\mathrm{P}_{2}\left(D_{n} \cong 380\right)$ において, 非対称二次流が分岐する. その分枝は，O,P を経て大きな $D_{n}$ へと進んでいく. 点O,P の二次流を図 8(O),(P) に示寸。 なお, 図に示 されている非対称流は $\psi=0$ の線が下に下がっている が，丁度正反対である $\psi=0$ の線が上に上がっている 流れも同一の $D_{n}$ で存在することが確かめられている。 図6中の各点における微小変動の時間的推移を知るた め, 変動の最大 $\sigma_{R}$ を持つ固有值 $\left(\sigma_{R}, \sigma_{I}\right)$ を示せ ば, A : $(-4.76,0), \mathrm{B}:(-5.43,22.9), \mathrm{C}:(-2.22$, $25.0), \mathrm{D}:(7.80,0), \mathrm{E}:(10.4,0), \mathrm{F}:(7.33,0), \mathrm{G}:$ 


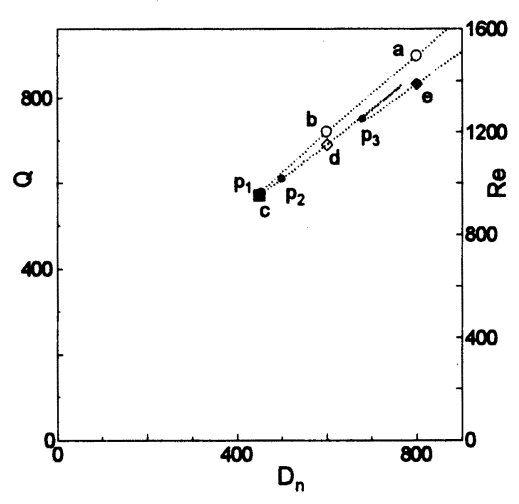

Fig.7 $Q$ versus $D_{n} \quad(\gamma=2)$

$(7.67,0), \mathrm{H}:(6.44,43.8), \mathrm{O}:(2.66,22.4), \mathrm{P}:(30.2$, 29.9)となっている.

図 7で示されるようなもう一つの二次流の分枝が存 在する. この解は全て不安定である. 図 7 における点 e での二次流は，図 9(e)に示されたように，八つ渦の 形態を持っている. この点より流量線図に沿って $D_{n}$ を下げるとき, $D_{n} \cong 678$ で流量の折り返しがあり， この点 $\mathrm{p}_{3}$ で二次流形態が八つ渦から六つ渦に変化す る. その後, $D_{n} \cong 770$ での尖点的な折り返しを経て 点 $\mathrm{d}$ を通り， $D_{n} \cong 500$ の点 $\mathrm{p}_{2}$ 八と至る. この点で 六つ渦から四つ渦人上変化する. 更に, $D_{n} \cong 450$ の 折り返し点を経て $p_{1}$ で四つ渦から二渦へと変化した 後, その形態を保った形で点 $b, a$ へとつ移っていく. 各点における渦形態を図9に示している.

$\gamma=2$ の場合, 図 6 によると $D_{n}$ がおよそ $376\left(R_{e} \cong 817\right)$ あたりで, 二つ渦から, 中央の渦が小 さい四つ渦に変化するように思われる. このとき， $D_{e}=R_{e} \sqrt{2 \delta}=163$ である. 杉山らけよひ秋山らけ の実験（それぞれの図 8(b)，図 3(b)）によると，二つ 渦が変化する $D_{e}$ は，それぞれ，180 $\left.\delta=0.0625\right)$ と $150(\delta=0.1)$ である. 本研究の形態変形 $D_{e}$ は実験と よく一致しているということがいえる. しかしながら, 実験における四つ渦は，図 9(c)で示されるような大き い中央渦の形態が得られている. 大きい中央渦を持つ 四つ渦は $D_{n} \cong 450(\mathrm{c})$, 従って $D_{e} \cong 190$ あたりで現 れることになっているので, その $D_{e}$ には大きな違い はないが, この二次流が不安定であること，小さい中 央渦を持つ四つ渦(D〜H)の方がまだ不安定度が小さ

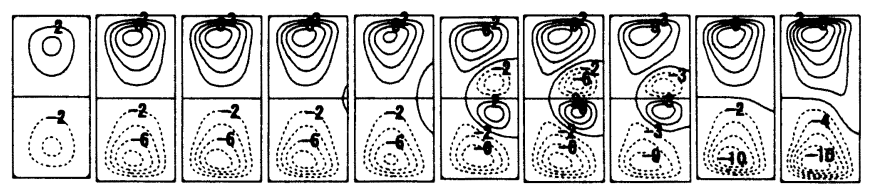
(A)
(B)
(C)
(D)
(E)
(F)
(G) (H)
(O)

Fig. 8 Secondary flow patterns $(\gamma=2): D_{n}=100(\mathrm{~A}), 300(\mathrm{~B})$, 355(C), 355(D), 300(E), 300(F), 400(G), 600(H), 400(O), 600(P).
(P)

い（530< $D_{n}<550$ では安定である）ことが $\delta$ の相 違する実験結果とは異なっている.

(iii) $\gamma=3$ の場合

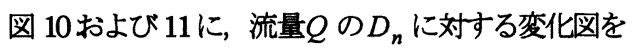
示す. 同図中の点 $A \sim E$ および $a \sim h$ での二次流模様

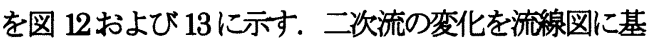
づて説明すると次のようになる. まず, 図 10 にお いて， $D_{n}$ が小さいところでは二つ渦である. A 点に おける流れ模様を図 $12(A)$ に示している. $D_{n}$ の増加 と共に点 $\mathrm{B}$ を経て, $D_{n} \cong 345$ での折り返し点 $\mathrm{P}_{2}$ に 至る. この間 $D_{n} \cong 262$ までは流れが安定である. 折 り返しの後, B の近くの点 $\mathrm{C}, D_{n} \cong 190$ の点 $\mathrm{P}_{1}$ を通 り, $D_{n} \cong 112$ でまた折り返す. その後, $D_{n}$ の増加 と共に D, E点を通り， $Q$ は増加する. この間, $\mathrm{P}_{1}$ 点 迄は二つ渦であるが, $\mathrm{P}_{1}$ 点から四つ渦となる. これ が一つの分枝である. もう一つの分枝は，点 $\mathrm{P}_{2}$ より 分岐する非対称流れである. 点 $\mathrm{O}$ での流れ模様を図 12(O)に示す. この場合にも， $\psi=0$ の流線が, 図 12(O)とは丁度反対に，上に上がった流れ模様も存在 する.

図 10 中の各点における微小変動の時間的推移を知 るため, 変動の最大 $\sigma_{R}$ を持つ固有値 $\left(\sigma_{R}, \sigma_{I}\right)$ を 示せば, $\mathrm{A}:(-4.03,0), \mathrm{B}:(3.08,31.3), \mathrm{C}:(9.68,0)$, $\mathrm{D}:(5.45,0), \mathrm{E}:(26.8,36.7), \mathrm{O}:(29.1,42.8)$ となって いる.

次に，解のもう一つの分枝である図 11 について説 明する. まず, $D_{n}=600$ の点 $\mathrm{h}$ では六つ渦となる.

その渦模様は図 13(h)に示されている. 流量線図に沿 って $D_{n}$ が小さくなるとき, 点 $\mathrm{g}$ を経て $\mathrm{p}_{2}$ へと至る が, この間六つ渦であり, $D_{n} \cong 317$ の点 $\mathrm{p}_{2}$ におい て四つ渦へと変化する. その後, e を経て, $D_{n} \cong 180$ において折り返した後， $\mathrm{d}$ 点， $\mathrm{c}$ 点を通り $\mathrm{p}_{1}$ （および b) 点へと至る. $\mathrm{p}_{1}$ は $D_{n} \cong 400$ にあり， この点から二つ渦人と変化する. 点 bでの流線図を図 13(b)に示す. 図 11 にはもう一つ分枝が示されてい る. すなわち, 点 $\mathrm{q}$ を含む分枝である. 点 $\mathrm{q}$ から $D_{n}$ が小さくなるとき, $\mathrm{p}$ 点を経て $D_{n} \cong 405$ で折り返し た後, 点 0 を通り， $D_{n} \cong 422$ の $\mathrm{p}_{3}$ 点に至る. ここ までは四つ渦である. 点 $\mathrm{p}_{3}$ において二つ渦へと変化

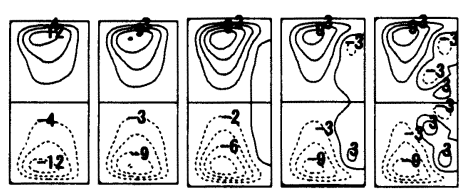
(a)
(b)
(c)
(d)
(e)

Fig.9 Secondary flow patterns $(\gamma=2)$ : $D_{n}=800(\mathrm{a}), 600(\mathrm{~b}), 450(\mathrm{c}), 600(\mathrm{~d}), 800(\mathrm{e})$. 


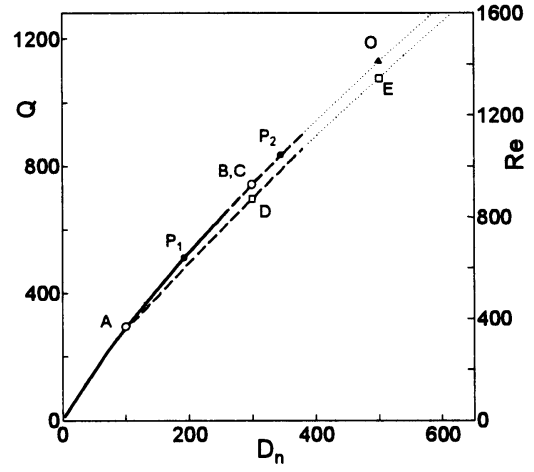

Fig.10 $Q$ versus $D_{n} \quad(\gamma=3)$

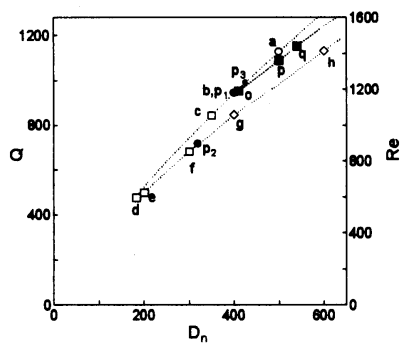

Fig.11 $Q$ versus $D_{n} \quad(\gamma=3)$

する.

図 10,11 によると, $D_{n}=262$, 従って $R_{e} \cong 830$ $\left(D_{e} \cong 166\right)$ までは二つ渦が観測され，その後，や や不安定ではあるが，二つ渦あるいは中央渦の小さ な四つ渦に変化するものと思われる.

(iv) $\gamma=4$ の場合

図 14 および 15 に流量 $Q$ の $D_{n}$ に対する変化を示す. 同図中の A〜O での二次流模様を図 16 に示寸. 二次 渦の変化は $\gamma=3$ に似たところがあるが，それを流量 線図に基づいて説明する. まず図 14 において， $D_{n}$ が小さいところ，例えば A では二つ渦である．その 後 $D_{n}$ の増加と共に, $D_{n} \cong 187$ の点 $\mathrm{P}_{1}$ までは安定な 二つ渦が続く.ここで流量は折り返しを行い， $D_{n}$ の 減少と共にほほ実線と平行に $Q$ は堿少する. $P_{1}$ 点で 折り返した後，流れはやや不安定となる。そして,

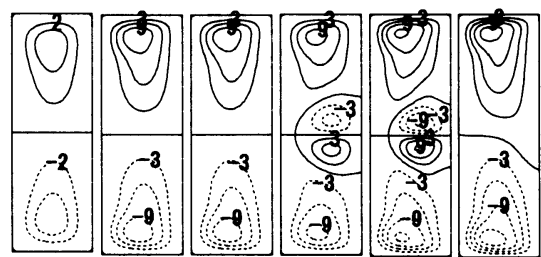

(A) (B)
(C)

(D)

(E)

(O)

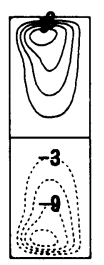

(a)

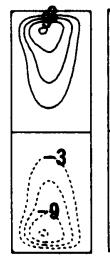

(b)
$D_{n} \cong 105$ の点 $\mathrm{P}_{2}$ で二つ渦から四つ渦に変化する. そ の後, 点 $\mathrm{B}$ を通り, $D_{n} \cong 79$ で再ひ折り返した後, $D_{n}$ の増加と共に $\mathrm{C}, \mathrm{D}, \mathrm{E}, \mathrm{F}$ 点を通って $Q$ は増咐る。 このときの四つ渦の中心部では小さい渦を形成してい る.

点 $\mathrm{P}_{1}$ からはもう一つの解が分岐する．それは， $\mathrm{P}_{1}$ から $\mathrm{P}_{3}$ 迄の弱い不安定な非対称流れ，それに続く $\mathrm{P}_{3}$ から $\mathrm{P}_{4}$ 迄の対称な二つ渦, $\mathrm{P}_{4}$ より先の不安定な非対 称流れとなっている.

図 14 中の各点における微小変動の時間的推移を知 るため, 変動の最大 $\sigma_{R}$ を持つ固有値 $\left(\sigma_{R}, \sigma_{I}\right)$ を 示せば, $A:(-2.64,0), B:(1.32,0), C:(1.39,0)$, $\mathrm{D}:(3.01,0), \mathrm{E}:(6.68,21.9), \mathrm{F}:(23.5,24.4), \mathrm{G}:(4.72$, 0), H : $(8.31,36.3), \mathrm{O}:(19.2,47.0)$ となっている.

図 15 に示されたもう一つの分枝における流れ模様 の変化は次のようである. まず, 点 $\mathrm{h}$ では, 六つ渦 流れである. $D_{n}$ が流量線図に沿って減少するとき, この六つ渦は， $D_{n} \cong 130$ の点 $\mathrm{p}_{3}$ (点 $\mathrm{e}$ において四つ 渦に変化する. そして, $D_{n} \cong 125$ の点 $\mathrm{d}$ で折り返し， $\mathrm{c}$ を経て, $D_{n} \cong 200$ の点 $\mathrm{p}_{2}$ (点 $\mathrm{b}$ ) 一と至る. 点 $\mathrm{p}_{2}$ に おいて四つ渦から二つ渦一と変化する. その後 $D_{n}$ の 増加と共に二つ渦が持続し, 図 14 の $\mathrm{P}_{3}$ 点に至る.

一方，もう一つの分枝上の点である $\mathrm{s}$ においては， 中心部の渦が大きい四つ渦が存在する.この四つ渦は, $D_{n}$ が流量線図に沿って減少するとき, $D_{n} \cong 176$ の 折り返し点を通り, 点 $\mathrm{p}$ を経て, $D_{n} \cong 285$ の点 $\mathrm{p}_{1}$ まで持続する. その後二つ渦へと変化し，図 14 の $\mathrm{P}_{4}$ 点に至る.

図 14, 15 で示された流れ模様変化から， $D_{n}=187$, 従って $R_{e} \cong 734\left(D_{e} \cong 147\right)$ までは二つ渦が観測され， その後は, 二つ渦, 四つ渦あるいは六つ渦の観測が可 能であると思われる.

以上のように，矩形曲がり管内層流に現れる二次流形 態は, ディーン数や管断面の維横比によって複雑に変 化するが，総体的には次のように言える. 生ずる二次 流は，ディーン数の增加と共に，二つ渦（ディーン

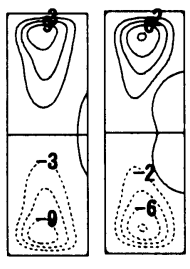

(c)

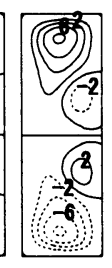

(e)

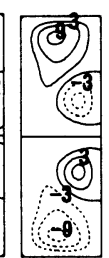

(f)

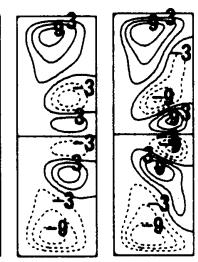

(g)

(h)

Fig. 12 Secondary flow patterns $(\gamma=3)$ : $D_{n}=100(\mathrm{~A}), 300(\mathrm{~B}), 300(\mathrm{C}), 300(\mathrm{D}), 500(\mathrm{E}), 500(\mathrm{O})$.

Fig. 13 Secondary flow patterns $(\gamma=3)$ : $D_{n}=500(\mathrm{a}), 400(\mathrm{~b}), 350(\mathrm{c}), 182(\mathrm{~d}), 200(\mathrm{e}), 300(\mathrm{f}), 400(\mathrm{~g}), 600(\mathrm{~h})$. 


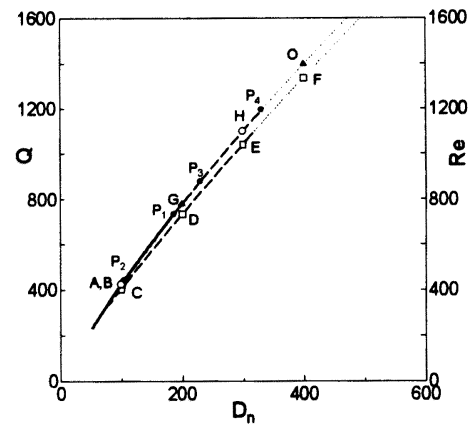

Fig. $14 Q$ versus $D_{n} \quad(\gamma=4)$

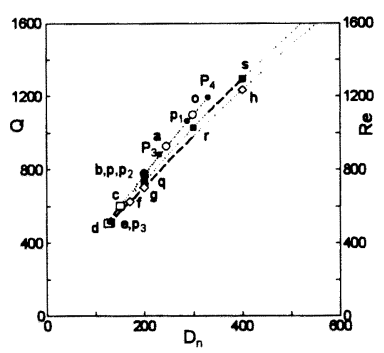

Fig.15 $Q$ versus $D_{n} \quad(\gamma=4)$

渦）から四つ渦へと変化するが，この変化は解の多重 性を伴っている. すなわち, ディーン数のある範囲に おいて，解曲線は多価となり，二つ渦と四つ渦が共存 する領域がある. 解曲線に沿っては，二次流は，二つ 渦から四つ渦へと漸次変化するが, ディーン数を単調 に増大させるとき，ある臨界ディーン数で四つ渦が突 然発生するように見える. このとき，外壁に向かう二 つ渦の流れが，外壁中心部附近で急激に止められ，上 下方向には速く流れ動くことから，それに引きずられ る形で外壁中心部に副渦が発生し，四つ渦になると考 えられる. ただし，この四つ渦は大部分不安定である. また，繸長な管では，解曲線が折り返すあたりから管 断面の中心線に対し非対称な二つ渦流れが分岐する. この非対称流も不安定である. 更に, 繸長な管では, 解曲線において, 第 2 の分枝が得られた. この分枝上 では，二つ渦を含むいくつかの異なった二次流の多重 解が存在する複雑な流れとなるが, 上下方向への移動 の容易さから，副渦も縋長な四つ渦や六つ渦などとな っている. なお，横長な管断面においては，上下方向 への移動が押さえられることから, 計算したディーン 数の範囲では，非対称解や，第 2 分枝解は得られてい ない.

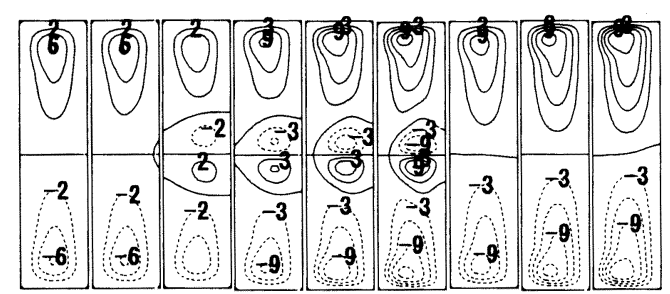
(A)
(B) (C)
(D) (E)
(F)
(G) (H)
(O)

Fig. 16 Secondary flow patterns $(\gamma=4)$ :

$D_{n}=99.5(\mathrm{~A}), 100.1(\mathrm{~B}), 99.6(\mathrm{C}), 200.3(\mathrm{D}), 300.0(\mathrm{E})$, $400.0(\mathrm{~F}), 200.0(\mathrm{G}), 300.4(\mathrm{H}), 399.9(\mathrm{O})$.

\section{5. 結 諭}

断面が矩形で無次元曲率 $\delta$ が 0.02 の曲がり管を通 る層流の定常解を求め, その安定性を解析することに より次の結論を得た.

（1）二つ渦から四つ渦への形態変化は，解の多重性 を伴って起こる. 二つ渦には安定な領域が存在するが, 四つ渦は大部分不安定である.

(2) 安定な二つ渦が存在する臨界ディーン数 $D_{n}$ は, 緹横比 $\gamma$ が 0.5, 2 3, 4 に対し，それぞれ，5500，376， 262,187 である. これらの值を $D_{e}=R_{e} \sqrt{2 \delta}$ で表せば, $256,163,166,147$ となる.

(3) $\gamma=2,3,4$ の場合, 複数の渦形態が存在するもう 一つの分枝解や，非対称渦の解が存在するが，それら の流れは不安定である.

終わりに, 数值計算のまとめに協力してくれた, 浅 原卓也君に感謝の意を表したい．

\section{文献}

(1) Ito, H., JSME Int. J., 30(1987), 543-552.

(2) Wimters, K, J. Fluid Mech., 180(1987), 343-369.

(3) Yanase, S., Kaga, Y., and Daikai, R., Fhuid Dynamics Research, 31(2002), 151-183.

(4) Cheng, K.C., Lin, R-C., and Ou, J-W., ASME. J. Fluids Eng., 98 1(1976), 41-48.

(5) 秋山光庸・ほか 5名,機論, 47-421, B(1981), 1705-1714.

（6）杉山司郎, 林太郎, 山崎公士, 機論, 48-434, B(1982), 1870-1876.

（7）柳瀬贞一郎, 大海隆二,森永努,機論, 64-626, B(1998), 3183-3190

(8) 柳瀬烦一郎·ほか 3 名,機論, 65-639, B(1999), 3622-3628.

(9) Gottlib, D. and Orszag. S.A., Numerical Analysis of Spectral Methods (Soc. Industrial and Appl. Math, 1981). 